\title{
Pengembangan Sistem Identifikasi Fitur Dua Dimensi Kekasaran Permukaan Berbasis Machine Vision untuk Produk Hasil Permesinan
}

\author{
Zulfan Yus Andi \\ Program Studi Teknik Perancangan Mekanik, Politeknik Manufaktur Negeri Bangka-Belitung, \\ SungaiLiat, Bangka 33211, Indonesia \\ Email: zulfan_ya@yahoo.com
}

\begin{abstract}
ABSTRAK
Kekasaran suatu produk merupakan salah satu standar keakuratan dan kualitas permukaan produk yang dihasilkan dari suatu proses permesinan. Nilai kekasaran ini sangat bervariatif, dilihat dari proses permesinan dan parameternya. Semakin halus permukaannya, semakin tinggi kualitas permukaan yang dihasilkan. Metode pengukuran kekasaraan dapat dilakukan dengan metode kontak dan metode non-kontak, salah satunya metode pengenalan citra, yaitu identifikasi citra dan pengolahannya.Hal ini disebut dengan metode machine vision. Cakupan penelitian ini meliputi pembuatan sistem pengukuran machine vision dengan menggunakan kamera saku digital pembesaran 4x, mikroskop pembesaran $20 \mathrm{x}$, pencahayaan (lighting) dan benda kerja hasil CNC bubut $\varnothing 36$ x $50 \mathrm{~mm}$. Selanjutya pemrosesan citra/image dengan perangkat lunak, yaitu identifikasi profil permukaan pelat kalibrator sebagai dasar pengukuran dan pengukuran terhadap benda ujinya. Pengukuran dilakukan dari puncak profil hingga lembah profil, sehingga memberikan kedalaman permukaan ukur. Dengan pengukuran machine vision pengenalan citra ini lebih mendekati nilai analitis, artinya tingkat kepresisian yang dihasilkan lebih mendekati nilai $R a$ natural, dengan rata-rata persentase penyimpangan yang dihasilkan $6.00 \%$.
\end{abstract}

Kata kunci: Kekasaran permukaan, fitur 2D, machine vision, pengolahan citra.

\begin{abstract}
Roughnessof aproductis oneof thestandards ofaccuracy and surface qualityof products result from a machiningprocess. The roughness value has varian cedepends on the machining processused. The finer the surface, the higher the surface quality produced. The roughness measurement method can be performed by contacts and non-contact method. One of non-contact method is image recognition, that are identification and image processing. This is called the machine vision method. This research includesof making the measurement system of machine vision consists of a pocket digital camera in scale of zoom 4 times, and microscope in scale of zoom 20 times, lighting, and CNC turning of workpiece with dimension $\varnothing 36 \times 50 \mathrm{~mm}$. And then development software for image processing, and measuring surface roughness of workpieces. Roughness average is measured frompeaks and valleys of surface profile, henceyields depth of average from surface roughness. By machine vision method for measuring depth of average from surface roughness, it is shown that the result more acurate from the contact method with percentage of deviation is $6.00 \%$.
\end{abstract}

Keywords: Surface roughness measurement, 2D features, machine vision, image processing.

\section{PENDAHULUAN}

Salah satu ukuran kualitas produk, dapat terlihat seberapa besar tingkat kekasaran permukaan yang dihasilkan dari suatu pemrosesan yang dilakukan. Pengukuran kekasaran permukaan telah banyak dilakukan [1-5]. Secara tradisional, metode yang umum digunakan adalah pengukuran profil meter atau stylus profile meter [1-5], (Gambar 1). Beberapa kelemahan pengujian ini, diantaranya stylus dapat merusak permukaan objek benda uji, kurangnya ketepatan fitur yang diukur karena dipengaruhi oleh dimensi bola ukur pada ujung stylus profile [2] dan diperlukan waktu analisis untuk menemukan nilai kekasaran tersebut.

Baru-baru ini, ada tiga jenis penelitian dengan metode non-kontak untuk mendeteksi permukaan kekasaran, yaitu metode pengenalan gambar, ultrasonik dan X-ray [3], seperti Gambar 2. Salah satu perlakukan pengukuran kekasaran dengan metodenon-kontak, dapat menghasilkan fitur profil 3D $[1,3,4]$, seperti Gambar 3. Pengukuran ini 
dilakukan dengan pengolahan citra dari hasil pengambilan citra (capturing image) dari kamera, mikroskop dan pencahayaan [6]. Image gray dari hasil capture tersebut dianalisa sehingga menghasilkan fitur kekasaran permukaan, dimana fitur ini dipengaruhi oleh pemakanan dari pahat potong pemrosesan mesin pada obyek benda kerja [4].

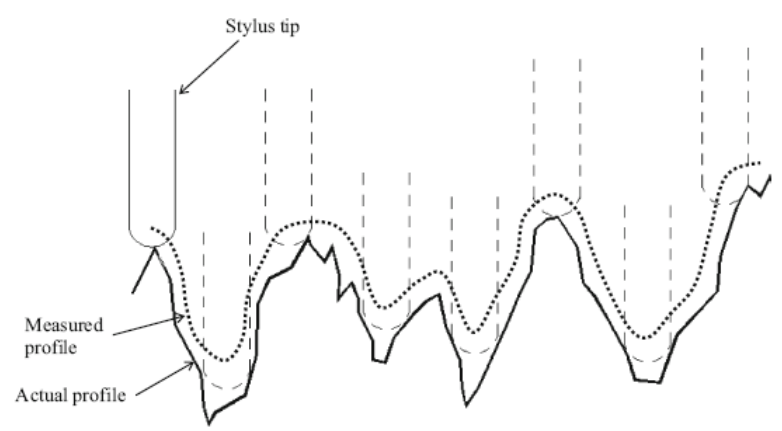

Gambar 1. Profil Actual dan Profil Pengukuran Menggunakan Metode Stylus [1]

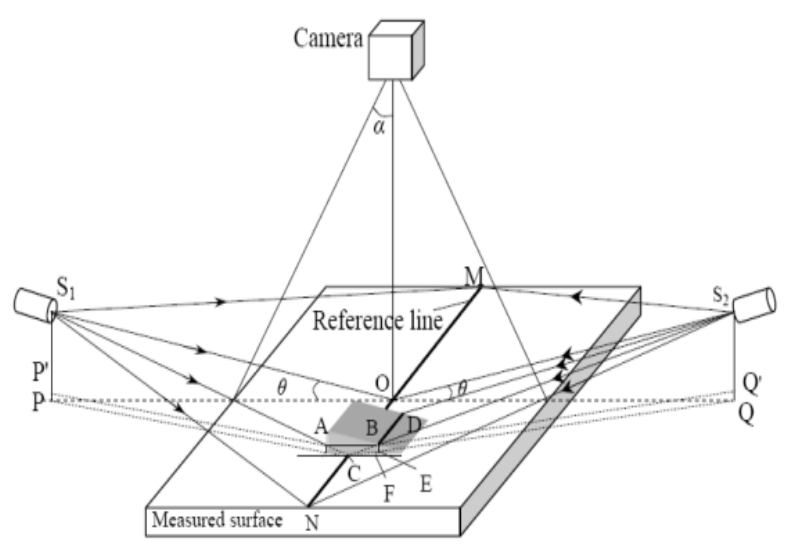

Gambar 2. Sistem Pengukuran dan Pencahayaan [2]

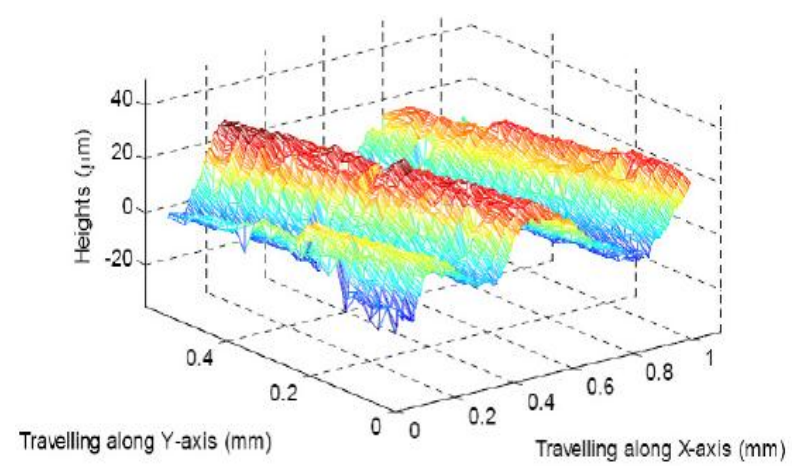

Gambar 3. Obyek Fitur Facing Turning [6]

Pada metode lain digunakan penggabungan $a$ light sectioning microscope and computer vision system untuk mengukur kekasaran. Vision system merupakan capture image untuk melihat profil kekasaran dengan pendetailan mikroskop dan untuk selanjutnya dilakukan pengolahan citra [6].
Juga pada identifikasi penelitian sebelumnya pengolahan citra masih memerlukan pengolahan algoritma yang baik, sehingga dianjurkan melakukan eksplorasi secara komputasi numerik untuk menemukan fitur yang lain sebagai pertimbangan dalam menemukan nilai kekasaran berbasis vision [4].

Tujuan penelitian ini adalah identifikasi profil atau fitur permukaan dari hasil pemrosesan mesin sehingga menghasilkan nilai ketinggian atau kedalaman rata-rata, dengan menggunakan metode nonkontak pengenalan citra.

Beberapa hal yang membatasi penelitian ini agar mencapai tujuan tersebut, adalah Obyek benda silinder $\varnothing 38 \times 50 \mathrm{~mm}$ sejumlah 10 buah hasil permesinan CNC bubut menggunakan pahat insert merk Korloy jenis CNMG120408-HS. Permesinan yang dilakukan dengan beberapa parameter, yaitu parameter tetap adalah kecepatan spindle 1414 rpm, kedalaman pemakanan $1.0 \mathrm{~mm}$, kecepatan pemakanan (Vc) $160 \mathrm{~m} / \mathrm{min}$ dan radius pahat $0.8 \mathrm{~mm}$. Dan parameter tidak tetapadalah batasan federate 0.1-0.4 $\mathrm{mm} / \mathrm{rev}(150-555 \mathrm{~mm} / \mathrm{min}$, increment $45 \mathrm{~mm} / \mathrm{min}$ ). Konstruksi sederhana pada image capturing obyek, yaitu mikroskop pembesaran 20x, digital pocket Nikon coolpixS3000; pencahayaan ke obyek dan menghasilkan citra jenis*.jpeg; Simulasi perangkat lunak MATLAB untuk pemrosesan dan peningkatan gambar; Pengukuran kekasaran rata-rata obyek uji.

\section{METODE PENELITIAN}

Dimulai denganstudi literatur yang berhubungan dengan tema penelitian baik dari jurnal nasional ataupun internasional, lalu dilanjutkan dengan membangun konstruksi sederhana dengan menggunakan mikroskop standar pembesaran/skala $20 x$, pocket camera pembesaran maksimal $4 x$ dan pencahayaan daya 20 watt, juga pengaturannya.

Pembuatan benda uji (workpiece) dilakukan pada permesinan CNC bubut dengan 10 variasi federate $150 \mathrm{~mm} / \mathrm{min}$ s.d. $555 \mathrm{~mm} / \mathrm{min}$ (increment $45 \mathrm{~mm} / \mathrm{min}$ ), bahan baja $S 45 \mathrm{C}$ (baja karbon dengan kadar karbon 0,45\%) dan kekuatan tarik $67 \mathrm{~kg} / \mathrm{mm}^{2}$ atau kekerasan $H B 187$ [7], dengan nilai kekerasan 55,7 HRA (High RockwellA). Alat potong pahat insert Carbide jenis CNMG120408-HS.

Sedangkan parameter pemotongan yang dilakukan untuk benda uji tersebut yaitu kecepatan potong (VC) $160 \mathrm{~m} / \mathrm{min}$; putaran spindle $1414 \mathrm{rpm}$; radius mata pahat $0.8 \mathrm{~mm}$; kedalaman pemakanan $1 \mathrm{~mm}$.

Melakukan perhitungan analitis terhadap benda uji dari inputan parameter proses permesinan CNC bubut dan parameter pahat insert. Sehingga terangkum nilai kekasaran ideal pada masingmasing benda uji untuk analisa dasar pada peng- 
ukuran pengenalan citra. Selain ini juga, melakukan pengukuran metode kontak dengan menggunakan stylus meter bertujuan untuk melihat perbandingan persentase analisa error pengukuran metode kontak dan non-kontak terhadap perhitungan kekasaran analitis.

Sebelum melakukan pengujian, terlebih dahulu melakukan kalibrasi dengan pengukuran pada pelat kalibrator roughtness permukaan kekasaran 0.40 $\mu \mathrm{m}$ atau $2.90 \mu \mathrm{m}$ sebagai kekasaran dasar untuk mendapatkan nilai kekasaran pada benda uji yang akan dilakukan.

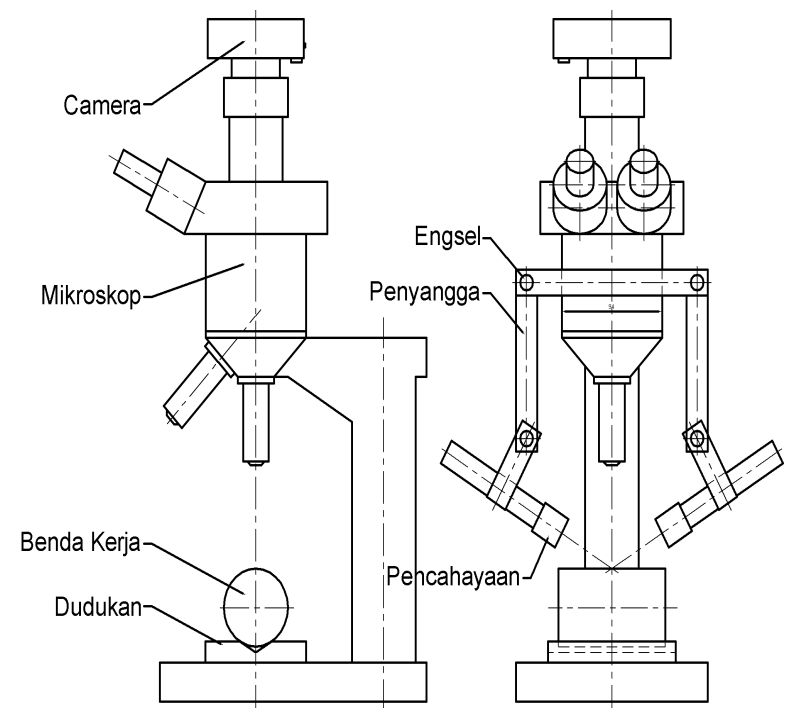

Gambar 4. Konstruksi Alat Pengukuran

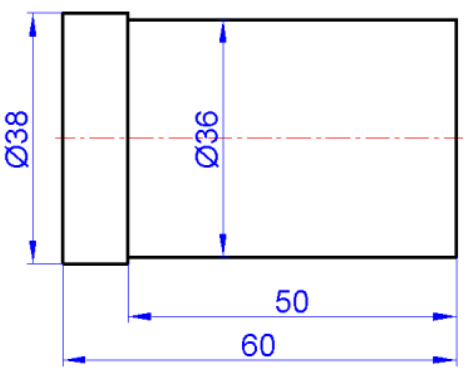

Gambar 5. Dimensi Benda Uji

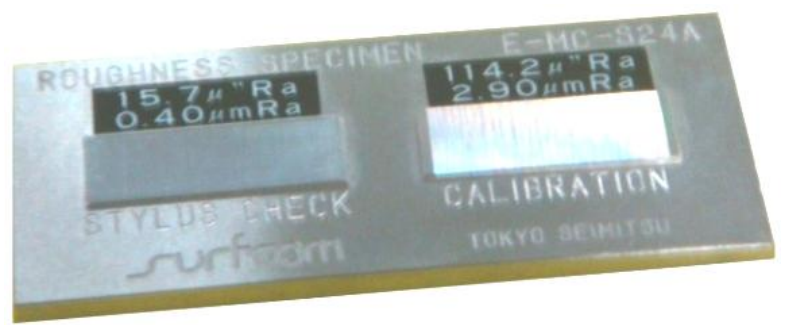

Gambar 6. Pelat Kalibrasi $0.40 \mathrm{~mm}$ dan $2.90 \mathrm{~mm}$

Kalibrasi pemrosesan citra, yaitu melakukan identifikasi tiap titik pixel, sehingga dapat mem- berikan bentuk profil permukaan kedalaman permukaan. Selanjutnya bentuk profil permukaan sebenarnya itu disimulasikan kembali untuk mengetahui bentuk profil garis linear, sehingga dapat diidentifikasikan batasan bagian lembah profil dan batasan bagian puncak profil. Agar nilai kalibrasi dapat teridentifikasi, yaitu melakukan pengukuran hasil kedalaman kekasaran yang dihasilkan pada permukaan obyek ukur pada pelat kalibrasi dan ditranspormasikan dengan nilai dasar pelat kalibrator kekasaran tersebut, sehingga menghasilkan nilai dimensi per-brightness.

Dari nilai kalibrasi dapatlah mengukur kedalaman permukaan seluruh benda uji yang telah di-capture dan memberikan $R a$ dari masing masingmasing feed rate yang berbeda.

\section{HASIL DAN PEMBAHASAN}

Mikroskop dibuat dudukan dari beberapa part pelat, diharapkan dapat memposisikan/mengarahkan pencahayaan ke titik obyek permukaan benda uji.

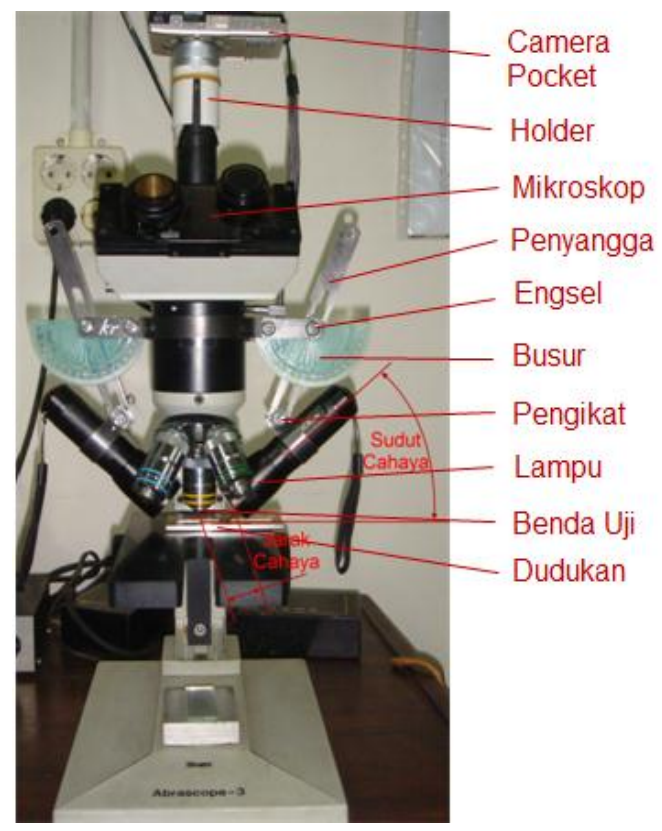

Gambar 7. Bagian-bagian dan Set-Up Konstruksi

Konstruksi ini dibuat bertujuan untuk mengatur sudut pencahayaan, jarak pencahayaan, pengaturan pembesaran skala objek dan pemposisian titik objek permukaan yang diambil. Set-up hasil pengujian yang dilakukan dapat terlihat pada hasil image capturing ini.

Dari hasil image capturingpada Gambar 8, dilakukan identifikasi bentukan profil sebagai batas ukur kalibrasi yang akan ditransformasikan dengan nilai kalibrator $0.4 \mu \mathrm{m}$ dan $2.9 \mu \mathrm{m}$. 
Pemrosesan citra input dari hasil image capturing obyek tidak luput dipengaruhi oleh pencahayaan yang terjadi pada permukaan obyek. Ketegasan nilai brightnes ini dapat disimulasikan jika berbentuk permukaan ideal seperti di bawah pengaruh dari pencahayaan secara bervariatif. Hasil pemrosesan menunjukkan kalibrasi pengukuran awal dari kalibrator tersebut, dengan nilai kalibrasi $0.0569 \mu \mathrm{m}$ perbrightness. Selanjutnya nilai ini ditransformasikan dengan pemrosesan citra terhadap benda uji dengan hasil kekasaran dari tiap feedrate yang berbeda-beda.

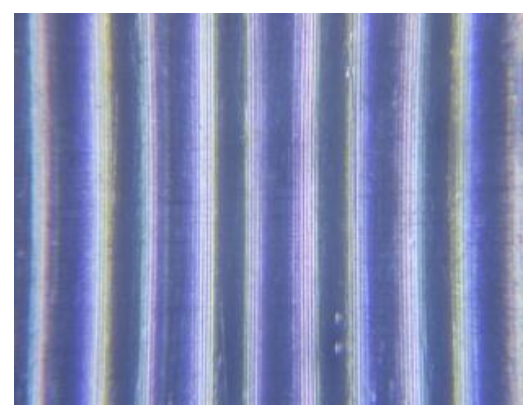

(a) Dengan sudut pencahayaan $30^{\circ}$

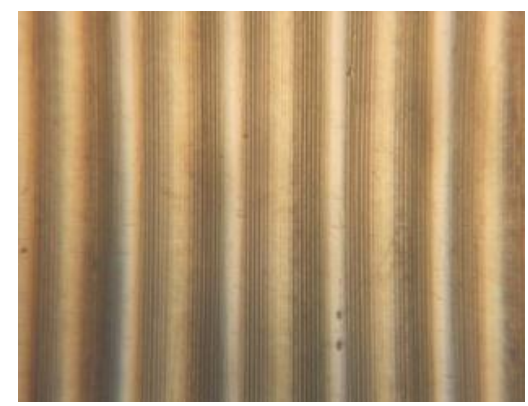

(b) Dengan sudut pencahayaan tegak lurus

Gambar 8. Hasil Image Capturing Permukaan Kekasaran $2.9 \mathrm{~mm}$ dengan Pembesaran $80 \mathrm{x}$

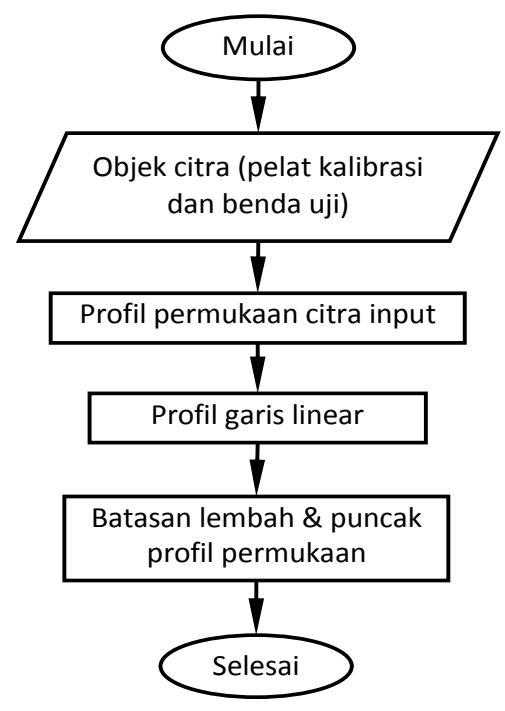

Gambar 9. Algoritma Image Processingdan Image Enhancemnet Bentukan Profil Permukaan Objek Ukur

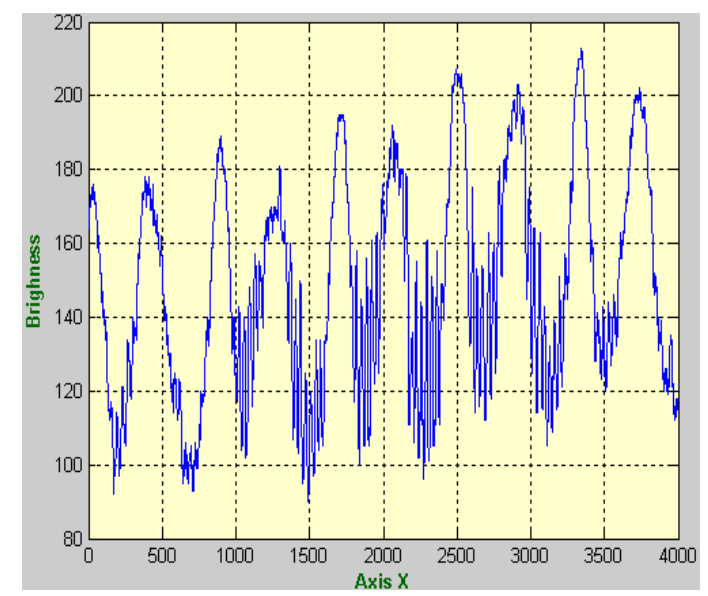

(a) Bentukan profil kalibrasi

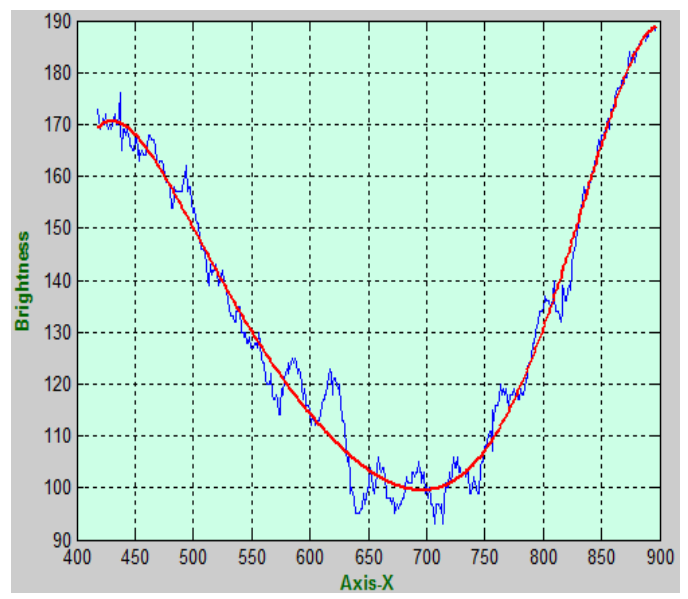

(b) Bentukan satu profil ukur

Gambar 10. Pemrosesan Citra
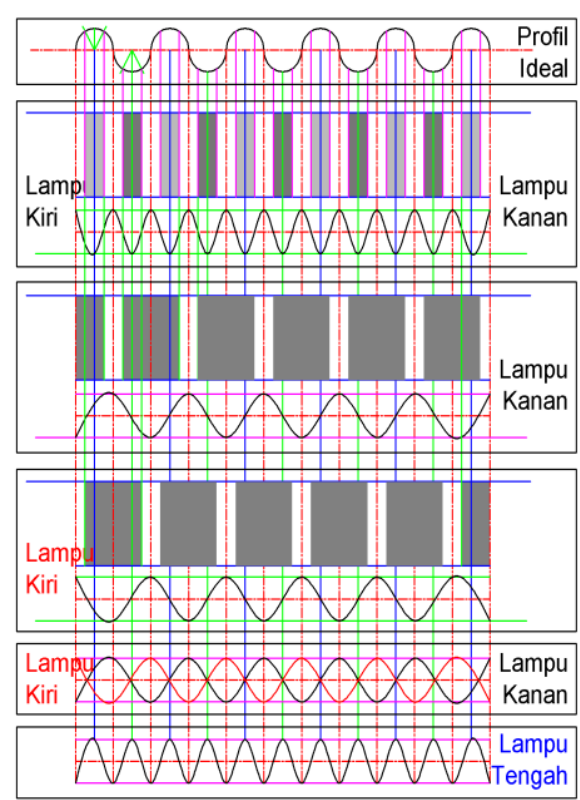

Gambar 11. Simulasi Grafis Bentuk Profil dari Bentuk Permukaan Ideal yang Dipengaruhi Nilai Brightness dari Sudut Pencahayaan Input 


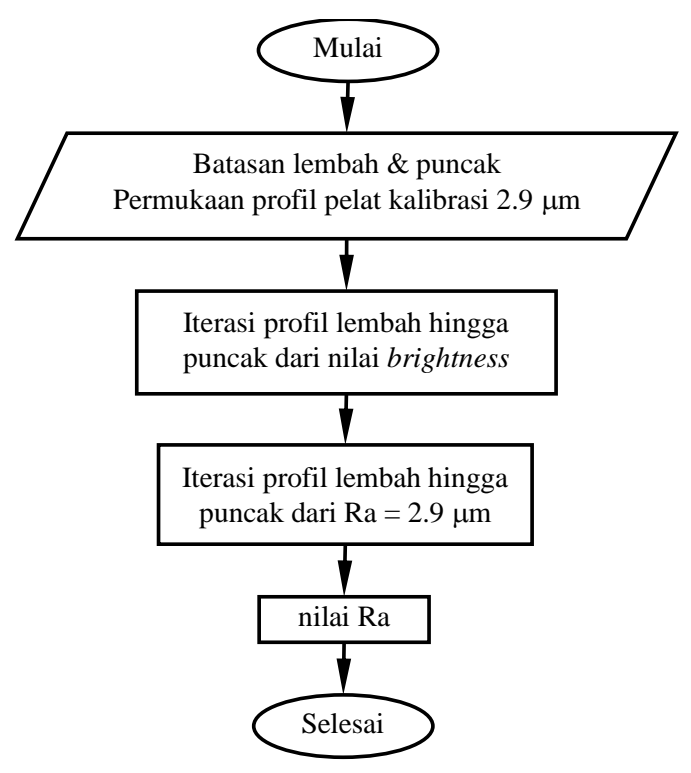

Gambar 12. Algoritma Pemrosesan Kalibrasi Pengukuran

Tabel 1. Hasil Pemrosesan Citra untuk Batasan Nilai dan $R a$ Objek Benda Uji dari Beberapa Feedrate yang Berbeda

\begin{tabular}{c|c|c|c|c|c|c|c}
\hline \multirow{2}{*}{$\begin{array}{c}\text { Feed } \\
\text { Rate } \\
(\mathrm{mm} / \mathrm{min})\end{array}$} & \multicolumn{2}{|c|}{ Batasan lebar profil } & \multicolumn{4}{|c}{$\begin{array}{c}\text { Batasan keting gian profil dari nilai } \\
\text { brightness }\end{array}$} \\
\cline { 2 - 9 } & Awal & Akhir & Range & Bawah & Atas & Range & Ra $(\mu \mathrm{m})$ \\
\hline \hline 150 & 2919 & 3739 & 820 & 137.00 & 191.2598 & 54.2598 & 0.9028 \\
\hline 195 & 1451 & 2535 & 1084 & 96.00 & 158.0582 & 62.0582 & 1.3465 \\
\hline 240 & 202 & 1617 & 1415 & 90.00 & 156.0062 & 66.0062 & 1.5711 \\
\hline 285 & 1377 & 2977 & 1600 & 91.00 & 177.8645 & 86.8645 & 2.7578 \\
\hline 330 & 1910 & 3561 & 1651 & 116.00 & 180.0804 & 64.0804 & 1.4615 \\
\hline 375 & 1663 & 3478 & 1815 & 108.00 & 173.1901 & 65.1901 & 1.5246 \\
\hline 420 & 1935 & 3340 & 1405 & 120.00 & 204.4057 & 84.4057 & 2.6179 \\
\hline 465 & 1547 & 3345 & 1798 & 92.00 & 190.3848 & 98.3848 & 3.4132 \\
\hline 510 & 1310 & 3428 & 2118 & 109.00 & 194.8137 & 85.8137 & 2.6980 \\
\hline 555 & 1403 & 3901 & 2498 & 104.00 & 200.1382 & 96.1382 & 3.2854 \\
\hline $\begin{array}{c}\text { Kalibrator } \\
0.4 \mu \mathrm{m}\end{array}$ & 208 & 275 & 67 & 116.4117 & 161.8348 & 45.4231 & 0.4000 \\
\hline $\begin{array}{c}\text { Kalibrator } \\
2.9 \mu \mathrm{m}\end{array}$ & 418 & 897 & 479 & 99.5268 & 188.8906 & 89.3638 & 2.9000 \\
\hline
\end{tabular}

Sedangkan hasil perhitungan analitis yang didapatkan dari parameter pemrosesan $\mathrm{CNC}$ bubut yang dilakukan dengan bentuk idealnya dan hasil pengukuran kontak (sylus meter).

Tabel 2. Hasil Perhitungan Analitis dari Bentuk Ideal Hasil Pemrosesan CNC Bubut dan Parameter-Parameternya

\begin{tabular}{c|c|c}
\hline $\begin{array}{l}\text { Feed Rate } \\
(\mathrm{mm} / \mathrm{min})\end{array}$ & $\begin{array}{c}\text { Feed rate } \\
(\mathrm{mm} / \mathrm{rev})\end{array}$ & $\mathrm{Ra}(\mu \mathrm{m})$ \\
\hline \hline 150 & 0.10607 & 0.4515 \\
\hline 195 & 0.13789 & 0.7630 \\
\hline 240 & 0.16971 & 1.1557 \\
\hline 285 & 0.20154 & 1.6297 \\
\hline 330 & 0.23336 & 2.1850 \\
\hline 375 & 0.26518 & 2.8216 \\
\hline 420 & 0.29700 & 3.5394 \\
\hline 465 & 0.32882 & 4.3385 \\
\hline 510 & 0.36064 & 5.2188 \\
\hline 555 & 0.39246 & 6.1804 \\
\hline
\end{tabular}

Tabel 3. Hasil Pengukuran Kontak Menggunakan Stylus Meter

\begin{tabular}{c|c}
\hline Feed Rate $(\mathrm{mm} / \mathrm{min})$ & $\mathrm{Ra}(\mu \mathrm{m})$ \\
\hline \hline 150 & 0.8080 \\
\hline 195 & 0.9360 \\
\hline 240 & 1.0160 \\
\hline 285 & 0.9720 \\
\hline 330 & 0.8720 \\
\hline 375 & 0.9360 \\
\hline 420 & 0.8600 \\
\hline 465 & 0.8200 \\
\hline 510 & 0.8960 \\
\hline 555 & 0.9080 \\
\hline Kalibrator $0.4 \mu \mathrm{m}$ & 0.680 \\
\hline Kalibrator $2.9 \mu \mathrm{m}$ & 3.356 \\
\hline
\end{tabular}

Dilihat dari nilai $R a$ pada masing-masing metode perhitungan dan pengukuran kekasaran rata-rata yang dilakukan, terangkum pada Tabel 4 .

Analisis hasil pengukuran kekasaran rata-rata yang ditunjukkan tabel dan grafik di atas bahwa pengukuran machine vision pengenalan citra lebih mendekati nilai analitis, artinya tingkat kepresisian yang dihasilkan lebih mendekati nilai Ranatural. Nilai kontak yang terjadi masih di bawah nilai kekasaran natural yang dihasilkan. Hal ini disebabkan karena pengaruh dari besarnya radius bola kontak sebagai pengukuran profil kekasaran permukaan yang didapatkan. Sedang persentase penyimpangan yang dihasilkan dari pengukuran kontak (stylus meter) dengan kekasaran natural rata-rata di bawah analitis $(-40.26 \%)$, dan nonkontak (pengenalan citra) terhadap kekasaran natural di atas analitis $6.0 \%$.

Tabel 4. Persentase Penyimpangan Nilai Kekasaran Metode Pengukuran Stylus (Metode Kontak) dan Machine Vision (Metode Non-kontak)

\begin{tabular}{|c|c|c|c|c|c|c|}
\hline \multirow{2}{*}{$\begin{array}{c}\text { Feed } \\
\text { Rate } \\
(\mathrm{mm} / \mathrm{min})\end{array}$} & \multicolumn{3}{|c|}{ Hasil Pengukuran $\operatorname{Ra}(\mu \mathrm{m})$} & \multicolumn{3}{|c|}{$\begin{array}{c}\text { Persentase } \\
\text { penyimpangan (\%) }\end{array}$} \\
\hline & Analitis & $\begin{array}{l}\text { Stylus } \\
\text { Meter } \\
(S M) \\
\end{array}$ & $\begin{array}{c}\text { Machine } \\
\text { Vision } \\
(M V)\end{array}$ & $\begin{array}{c}\text { SMvs } \\
\text { Analitis }\end{array}$ & $\begin{array}{l}\text { MV vs } \\
\text { Analitis }\end{array}$ & $\begin{array}{c}\text { MV vs } \\
\text { SM }\end{array}$ \\
\hline 150 & 0.4515 & 0.808 & 0.9028 & 78.98 & 99.97 & 11.73 \\
\hline 195 & 0.7630 & 0.936 & 1.3465 & 22.68 & 76.48 & 43.85 \\
\hline 240 & 1.1557 & 1.016 & 1.5711 & -12.09 & 35.94 & 54.63 \\
\hline 285 & 1.6297 & 0.972 & 2.7578 & -40.36 & 69.22 & 183.72 \\
\hline 330 & 2.1850 & 0.872 & 1.4615 & -60.09 & -33.11 & 67.60 \\
\hline 375 & 2.8216 & 0.936 & 1.5246 & -66.83 & -45.96 & 62.89 \\
\hline 420 & 3.5394 & 0.860 & 2.6179 & -75.70 & -26.03 & 204.41 \\
\hline 465 & 4.3385 & 0.820 & 3.4132 & -81.10 & -21.33 & 316.25 \\
\hline 510 & 5.2188 & 0.896 & 2.6980 & -82.83 & -48.30 & 201.12 \\
\hline 555 & 6.1804 & 0.908 & 3.2854 & -85.31 & -46.84 & 261.83 \\
\hline \multicolumn{4}{|c|}{ Rata-rata } & -40.26 & 6.002 & 140.80 \\
\hline
\end{tabular}




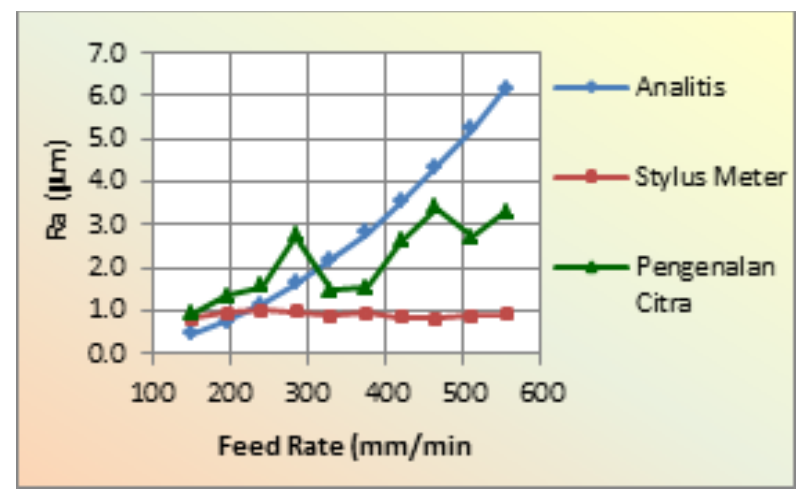

Gambar 13. Grafik Nilai Kekasaran dari Perhitungan Analitis, Pengukuran Metode Kontak dan Metode NonKontak

\section{KESIMPULAN}

Karakteristik yang mempengaruhi pengukuran kekasaran dengan metode pengenalan obyek pada machine vision ini adalah capture image (set-up external terhadap kualitas citra yang ditangkap), identifikasi profil dari pemrosesan citra input dan transformasi identifikasi kalibrasi ke pengukuran benda uji.

Dengan melakukan kalibrasi pemrosesan citra pada pelat kalibrator maka didapatkan iterasi pengukuran profil $0.0569 \mu \mathrm{m}$ per brightness sebagai dasar pengukuran benda uji.

Hasil pengukuran non-kontak yang dilakukan memberikan hasil yang mendekati nilai kekasaran natural dibandingkan dengan metode kontak, ini menunjukkan ketelitian pengukuran non-kontak terarah pada tingkat ketelitian yang cukup tinggi. Dengan persentase penyimpangan rata-rata $6.00 \%$.

\section{DAFTAR PUSTAKA}

[1] Shahabi, H. H. \& Ratnam, M. M., Non-contact Roughness Measurement of Turned Parts using Machine Vision, DOI10.1007/S00170-009-21010, International Journal Advanced Manufacturing Technology, 46: pp. 275-284, 2010.

[2] Rakiman, Studi Eksperimental Pengukuran Kekasaran Permukaan Dengan Metode Electronic Speckle Pattern Interferometry (ESPI), TesisRM2702, 2007.

[3] Xiaojun, T., et al., Surface Roughness Measurement Based on Image Processing and Image Recognition, Jurnal Computers and Simulation in Modern Science, China, ISSN: 1790-2769, ISBN: 978-960-474-117-5,pp. 91-96.

[4] Budi, H., Identifikasi Fitur 2D Kekasaran Permukaan Berbasis Vision untuk Produk Hasil Permesinan, Tesis DTM-UI, 2009.

[5] Thivakaran, T. K., and Chandrasekaran, R. M., Machine Vision based Surface Roughness Measurement with Evolvable Hardware Filter, ICGST-GVIP Journal, Volume 10, Issue 3, pp. 11-19, www.icgst.com, 2010.

[6] Ossama, B. A., 3D Surface Roughness Measurement Using a Light Sectioning Vision System, ISBN: 978-988-17012-9-9, Proceedings of the World Congress on Engineering, Vol I, London, U.K., 2010.

[7] Ninuk, J., Pengaruh Parameter Potongdan Geometri Pahat terhadap Kekasaran Permukaan pada Proses Bubut, Jurnal Teknik Mesin, Vol. 1, No. 1: 82-88, April 1999. 